\title{
A Woman Alone: The Depictions of Spinsters in Irish Women's Short Stories ${ }^{1}$
}

\author{
Ann Wan-lih Chang \\ Shih-chien University, Kaohsiung Campus, Taiwan
}

Copyright (c) 2015 by Ann Wan-lih Chang. This text may be archived and redistributed both in electronic form and in hard copy, provided that the author and journal are properly cited and no fee is charged for access.

\begin{abstract}
This paper focuses on the manner in which single women are represented in contemporary Irish women's short stories. Typically in these stories, such women are portrayed as a distinctive social group within a society in which a traditionally negative image of the spinster has been reinforced by a dominant social ideology which has as objective the exertion of social control over women. Contemporary Irish female writers attempt to ridicule this problematic "single-woman phobia" by demonstrating that this phenomenon is actually the result of women's "selflessness" rather than the "selfishness" associated with the spinster stereotype. Irish women's stories demonstrate also a fundamental unfairness inherent within Irish society in which women are compelled to sacrifice their own lives and needs for the benefit of others by assuming a surrogate mothering role as "social mothers". Ironically, this paradox acts as the main obstacle preventing Irish spinsters from fulfilling their roles as wives and biological mothers. In response, Irish female writers de-demonise the witchlike spinster stereotypes by deconstructing through their narratives those paradoxical social norms which have actually nurtured and reinforced negative perceptions of the "single women" within Irish society.
\end{abstract}

Key Words. Spinster Stereotype, Single Women, Alienation, Social Outcast, Social Mother.

Resumen. El artículo se centra en la manera en que las mujeres solteras están representadas en relatos de escritoras irlandesas contemporáneas. Normalmente, en estas historias, dichas mujeres son retratadas como un grupo social distintivo, en una sociedad en la que la imagen tradicionalmente negativa de la solterona ha sido reforzada por una ideología social dominante que tiene como objetivo el ejercicio de control social sobre las mujeres. Las escritoras irlandesas contemporáneas tratan de ridiculizar esta problemática fobia hacia la mujer soltera demostrando que esta condición no se debe al carácter "egoísta" asociado al estereotipo de la solterona, sino que deriva precisamente de su actitud "generosa". Los relatos escritos por autoras irlandesas demuestran también una injusticia fundamental inherente a la sociedad irlandesa en la que las mujeres se ven obligadas a sacrificar sus propias vidas y necesidades para beneficio de otros, asumiendo un rol maternal como "madres sociales". Irónicamente, esta paradoja actúa como el principal obstáculo para que las solteronas irlandeses puedan cumplir su papel de esposas y madres biológicas. En respuesta, las escritoras irlandesas desdemonizan los estereotipos de la solterona arpía, desconstruyendo a través de sus narraciones esas normas sociales paradójicas que en realidad han alimentado y reforzado la percepción negativa de las "mujeres solteras" dentro de la sociedad irlandesa.

Palabras clave. Estereotipo de la solterona, mujeres solteras, alienación, marginación social, madre social.

1. The research for this paper was conducted in the framework of the project Iphigenia's Outcry: Sacrificial Women in Irish Women's Stories (2012-2013), funded by Shih-chien University (grant reference USC 101-05-06006). 


\section{Introduction}

This paper focuses on a group of female characters who have never been married and whose role within Irish society is, therefore, not defined by marriage or child rearing. In this paper we draw on the perspectives of Irish female writers whose works cover, overall, the entire second half of the twentieth century Mary Lavin in the pre-1960's, Maeve Kelly, Emma Cooke, Clare Boylan, Jan Kennedy in the 1970's and 80's, Mary Beckett, Angela Bourke and Claire Keegan in the 1990's. Running through the works of these writers is a core theme of generalised hostility within Irish society towards women who, by choice or circumstance, have remained single. The stories by these writers return consistently to portrayals of the force exerted upon women by society to conform through self-sacrifice in a cultural environment which emphasises the benefit of society in general at the expense of women. These stories dissect the social ideology underlying and underpinning the politics of gender roles and human interaction within Irish society. The stories achieve this goal by choosing themes and issues of alienation, internal exile and prejudice against spinsters, and setting these against a backdrop of an ideological manifestation of a "spinsters as odd women" stereotype as well as of a requirement for women to conform to a role of selfless "social mothers". The social norm shaping women into natural wives and mothers serves, in effect, as a means of social control over women (Mustard 2004 "Spinster"). Representations of a negative image of single women as spinsters in these stories indicate the continuing social marginalisation and discrimination which this distinctive (single women) group experiences as a result of falling outside of the conventional social enclosure in Ireland.

The social phenomenon in post-famine

2. See also L. J. Peach's Women in Culture: A Women's Studies Anthology (1998), Oxford: Blackwell; Sheila Jeffreys' The Spinster and Her Enemies: Feminism and Sexuality 1880-1930 (1985); Pat O'Connor's Emerging Voices: Women in Contemporary Irish Society (1998).
Ireland in which a growing number of women stayed unmarried or permanently celibate is not unique in the context of modern Western Europe. ${ }^{3}$ Like other western European countries, Ireland also experienced rural depopulation. Given that Ireland was, and remains, a stronghold of the belief that the role of women lay in domesticity and motherhood, a belief reinforced by the rejection of birth control of any kind, it is worth noting that the demographic patterns of population growth in Ireland since the Great Famine up to the 1960s remained much lower than in many other European countries. Partly, this demographic pattern may be due to "the combined effects of large-scale emigration and the lowest marriage rate in Europe" (Murphy-Lawless 1993: 53). ${ }^{4}$ The feasibility of attaining married status for Irish men and women may also have been limited in many respects by practical factors and available economic options. The tightening economic conditions resulted in a gradual change in the system of land inheritance amongst rural farmers. Typically, only the eldest son could inherit his father's

3. The discussion does not include Catholic nuns who vow to serve God as "brides" of Christ. Nor is the aim of this paper to study single men (so-called bachelors) here as this goes beyond the scope of this paper. For more about the demographic analysis of Ireland see Timothy W. Guinnane, 1997, "The Vanishing Irish: Ireland's Population from the Great Famine to the Great War", History Ireland, Vol.5, Issue 2, Summer, http://www.historyireland.com/ 20th-century-contemporary-history/the-vanishingirish-irelands-polulation-from-the-great-famine-tothe-great-war, [retrieved: 7/04/2014]. See also Jo Murphy-Lawless, 1993, "Fertility, Bodies and Politics: The Irish Case", Reproductive Health Matters, No. 2 Nov, 53-6; Patrick Clancy, et al, 1995, Irish Society: Sociological Perspectives, Dublin: The Institute of Public Administration; Beverly I. Strassmann, and Alice L. Clark, 1993, "Ecological Constraints on Marriage in Rural Ireland", Evolution and Human Behavior, 19, 33-55.

4. See also L. A. Clarkson, 1981, "Marriage and Fertility in Nineteenth-Century Ireland", Marriage and Society: Studies in the Social History of Marriage, ed, R. B. Outhwaite, New York: St. Martin's Press, 237-55. 
land and therefore only the eldest son would have been in a practical position to marry and raise a family of his own. As a result, the younger siblings either had to stay single or leave, or possibly both (Clarkson 1981: 237-55; Strassmann and Clark 1998: 38). At that time, many single women left the country to escape poverty and perhaps also social pressure resulting from their continuing single status (Horgan 2001 "Women's Lives").

The 1937 Constitution emphasises that the primary role of women in Irish society was that of wife and mother, a reflection of a dominant view that "the family was a moral institution, possessing inalienable and imprescriptible rights" (Murphy-Lawless 1993: 54). Marriage in general becomes the social norm, or default option, for women inasmuch as women are largely defined in Irish society by the roles and duties in which they engage within the enclosure of marriage. Even today, social identities of Irish women continue to be constructed in the domestic arena of marriage and motherhood despite Ireland's economic modernisation as a member of the European Community, a theoretical availability of greater choice to women through access to higher education, and the impact of women's movements (Byrne 2008: 19). Pat O'Connor argues that the domestic roles of Irish women such as caring, reproduction and family management are deemed by the state and the church to be "key elements in the definition of womanhood. Love and sexual attraction ... effectively obscure the issue of state control" (O'Connor 1998: 155). This is also the picture which comes through in many representations of the (seemingly more or less obligatory) pursuit of love alongside marriage in contemporary Irish women's short stories. However, there is a double-bind paradox underpinning this seemingly central status of marriage and family in Irish society. On the one hand, the state and the church emphasise the essential role of family and motherhood. On the other hand, the ideologically based sexual repression supported by Irish politics and Catholicism was actually a contributory factor in the patterns of late marriage and permanent celibacy which seemed to "become the norm in Ireland" until the second half of the 20th century (Horgan 2001 "Women's Lives"). This odd phenomenon in Ireland is also mirrored in Irish women's stories in which some women do not stay celibate or single by choice but do so under duress from circumstances beyond their control.

\section{Spinsters as Odd, Neurotic or Evil Caricatures}

Anne Byrne, an Irish sociologist at NUI Galway, starts her chapter "Single women in Ireland" in Women on Their Own: Interdisciplinary Perspectives on Being Single (2008) as follows:

\begin{abstract}
...single women, born in the 1950s and 1960s, reveal the identity effects of the ideology of marriage and family that continues to resonate in contemporary Irish society despite the economic and social forces of modernity. Familistic ideologies positively support constructions of womanhood as married and mother, a context in which singlehood and the opposition between woman identity and single identity are problematic. In the absence of positive and powerful counternarratives, singlehood is disparaged and stigmatized, constraining the identity possibilities for all women (Byrne 2008: 16). ${ }^{5}$
\end{abstract}

Byrne's study identifies a clear association of women's singlehood, even in contemporary Ireland, with social inadequacy and exclusion. Single women can be seen to form a group clearly "marked by 'social sufferings', a consequence of their non conformity to the cultural hegemony of marriage and family... Single women [in fact and fiction] are a threat to family...[S]ingleness [is viewed] as a deviant social identity" (Byrne 2008: 17, 22). Spinsters (or single women, to use a less negatively loaded term) never actually disappear but, rather, remain silenced throughout history. The stereotype of such figures in literature can be traced to an ideology deeply embedded in the history and psyche of western culture and society.

The spinster stereotype as manifested in Irish women's stories may be easier to analyse if we first consider the term spinster and its associations within the cultural contexts of western societies. The term "spinsters" originally referred to women who worked as spinners to earn their own living, and then evolved into a synonym for those who are

5. See also Anne Byrne's "Singular Identities: Managing Stigma, Resisting Voices", Women's Studies Review, 7, 2000: 13-2 
usually long past their "sell-by date" for marriage and thus had to earn their keep in the parental home by spinning and weaving. ${ }^{6}$ Although semantically the primary definition of the term spinster is someone (usually a woman) who spins thread or yarn, or who practices spinning as a regular occupation, according to both the New Oxford Dictionary of English and the Webster's New World Dictionary of the American Language, the secondary definition refers to a woman who is beyond the usual age for marriage, in other words, an old maid. The word spinster may even be used in a secondary, negative way to refer to single women in general (Weigle 1982: 30). ${ }^{7}$ This particular term, spinster, which first appeared as a designation of an unmarried woman (regardless of whether young or old) in court documents in England in medieval times, has been associated with negative images of women in the literature of Protestant England since the 18th century and this negative association seems subsequently to have spread to other European countries and to America (Froide 2005: 154$6) .{ }^{8}$ The resulting growth in social anxiety due to the rising number of single women transformed the spinster in media and literature into a negative caricature implying women who are typically middle-aged, eccentric, illnatured, selfish or even evil.

Nevertheless, in the late 19th century, when the first wave of feminism began to spread widely across Europe and America, this traditionally negative term was once adopted by feminist activists such as Cicely Hamilton in a way that had a positive association, as part of a political strategy targeted against the tyrannical, maledominated marriage institution and mandatory

6. For more see Patricia O'Brien's The Woman Alone (1973).

7. As the highly valued skills of spinning and weaving cannot easily be mastered to a high standard by all women, according to Martha Weigle, the use of the term may suggest that considerable tension or doubt about "one's womanly competence, anger at difficult or dreary tasks, fear of failure or of not winning a mate". For more see Marta Weigle's Spiders and Spinsters (1982), Albuquerque: University of New Mexico Press.

8. See also Judith M. Bennett and Amy M. Froide (eds.), 2011, Singlewomen in the European Past: 1250-1800, Philadelphia: University of Pennsylvania Press. heterosexuality (Hamilton 1909: 37, 251-2; Jeffreys 1985: 91-2). ${ }^{9}$ This Victorian feminist rejection of an unjust marriage system finds echoes amongst contemporary Irish female writers in many of their depictions of women's lives which deal with what Irene BoadaMontagut has termed compulsory marriage. ${ }^{10}$ The status quo of gender politics is secured once women are forced into marriage and family, and therefore have to obey. If women fall, for whatever reason, outside this domain, they risk either being demonised or expelled as social outcasts so as to intimidate younger women into not following a similar path. Single women also tend to be forced to adopt a surrogate mothering role as carers, which once again limits women's scope to pursue the same life or career options as their male counterparts. Hence, female characters in Irish women's stories are sometimes forced by circumstances to become spinsters because they are pressurised to give up their lives (including marriage) and serve their parents at home. This seems ironic when compared to the stereotype which assumes that spinsters simply stay home as parasites because they are selfish enough to run away from their predestined childbearing responsibility to family and society.

A spinster may be represented stereotypically as a comic, grotesque, ugly, dull woman, or as an alienated misfit who displays a pitiful prudery and who is incapable of a human connection due to her "failure" to achieve a relationship with a man (Auerbach 1982: 111). M. Haskell describes the collective image of the spinster stereotype as follows:

Like witch, spinster, was a scareword, a stereotype that served to embrace and isolate a group of women of vastly different dispositions, talents, situations, but whose common bond never having become half of a pair - was enough to throw into question the rules and presumed priorities on which society was founded (Haskell 1988: 18).

The main underlying factor in the social isolation which characterises the literary portrayals of single women appears to be that

9. Here referenced and cited from the chapter "Spinster and Celibacy" (Jeffreys 1985: 86-101).

10. For more see the second chapter in Irene BoadaMontagut's Women Write Back, Dublin: Irish Academic Press, 2003: 46-81. 
people either dislike or fear them. As a result, they are excluded. They are even portrayed as evil witchlike figures. ${ }^{11}$ The spinster stereotype also tends to mock and demonise the single woman as one who is barren, "frumpy, middleaged" or "somewhat depressed, and is longing to be like other normal women" [italics my own] (Mustard 2004 "Spinster"). The image of a pathetic, neurotic, single woman who envies and longs to be like other normal women is another aspect of the stereotype. From this point of view, a single woman's life is never complete without marriage. The idea that a single woman can enjoy a fulfilled life outside marriage is inevitably looked upon with suspicion by the general majority within society.

\section{Spinsters as Social Outcasts and Monsters in Irish Women's Stories}

In her stories "Miss Holland" (1938) and "A single Lady" (1950), Mary Lavin identified single women's exclusion from the marriage enclosure as a key factor in their additional exclusion from mainstream society. Lavin (1912-1996), a doyenne amongst twentiethcentury Irish female writers, wrote many stories depicting the struggles of such marginalised women. Typically, these marginalised women are faced within the rural Irish community both by a generally hostile social environment and by a similar hostility from those in their immediate family and social circle. The characters in Lavin's stories are often shown as powerless and existing on a level of "internal exile" (Arndt 2002: 113). The rural context of the 1930s in which Lavin sets her stories may look, superficially, very different to that of contemporary Ireland. Nevertheless, Lavin's portrayal of the social and ideological imperatives imposed upon women in order to make them conform to prevailing social norms still have contemporary relevance. Single women in Ireland still struggle to negotiate self-fulfilment within the diverse strands of

11. The association between single women and witchcraft has its roots in the description of witches in some European folk traditions as women whose abilities and activities extended beyond childbearing and nursing into knowledge of healing, herbs or midwifery. See Martha Weigle's Spiders and Spinsters (1982). conceptions of womanhood. The prevailing, socially accepted norm would be heterosexual, married and reproductive contrasting with an equally prevalent view that single womanhood denotes "lack, as deviant and as a threat to the patriarchal order" (Byrne 2008: 19). Mary Lavin's spinster character in "Miss Holland" is one such figure who fails to fit in with the conventional notion of what a woman should be. She struggles to interact with other people and with her need to achieve an acceptable identity within society. The eponymous heroine of "Miss Holland" is tormented by her self-conscious awkwardness resulting from some internalised societal shame, which (to her) excludes spinsters from social interaction (Pratt 1982: 117). She tends to be troubled by her own self-imposed shame and lack of confidence. Struggling with complex feelings to try to locate herself in a society which provides little space for single women, the heroine tries hard to join other people in order to obtain the desired approval of, and identification within, this society: "[s]he would tell them all these little things and they would see that she was not stupid and dried-up, and they would see that she was worth getting to know and that her company was worth cultivating" (TB 153). ${ }^{12}$ Miss Holland's limited social experience is also due to her having spent most of her youth taking care of her elderly father at home, fulfilling the role of the typical dutiful (spinster) daughter often depicted in Irish women's stories. Miss Holland is naive and childlike in the way she observes a cat and compares it imaginatively to a Spanish dancer. However, such qualities as shyness, naivety or childishness in a middleaged spinster appear not as charming but as grotesque and pathetic in the eyes of other people in the story. These characteristics portray Miss Holland as a figure who stands out from other people through the awkwardness of her manners in a society otherwise indifferent to spinsters.

The spinster's stereotypical characteristics of prudery and hostility towards other people characterise Isabel, a sullen, possessive, jealous

12. Mary Lavin's Tales from the Bective Bridge (1978). Hereafter the cited references will be referred to as $T B$ with pagination. 
And calculating daughter, in another of Lavin's stories about a single woman, "A Single Lady" (1950). Once again, this spinster has spent most of her life with her father as a dutiful daughter. Somehow this daughter's selfless devotion is adulterated by a sense of legitimate authority over and possessiveness towards not only her father but also his financial investments. Perhaps Isabel's hostility towards the housemaid is more than simply the fear that her father may find a younger partner and companion, a woman who contrasts with the singlehood of Isabel herself, to replace her in his late years. Isabel's prudery drives her to loathe the seemingly seductive housemaid who is detested by her as a dirty, untidy "creature" of "slyness" with "no shame" and "no modesty", who wants to take advantage of the old man in order to obtain material benefit $(M L 156,58) .{ }^{13}$ This is reflected in Isabel's suspicious speculation about the housemaid's motive for patching the old corset, and in Isabel's resentment at being seen as ignorant in respect of sexuality, an area from which Isabel as a spinster is barred. The "revolting nature" of Isabel's thoughts suggests potential sexual activity in which the housemaid attempts to seduce her father, since Isabel thinks her father as an old man has become "unaccountable" for his behaviour "subject to [old men's] peculiar physical disturbances" (ML1 59). The daughter's jealousy and anger rise to a climax when she realises the glances of her father and the housemaid are "so heavy with intimations" that "[s]omething seemed to hold them bound together as one" (ML1 68). Isabel's malicious and hysterical reaction displays a dark image of a sullen spinster in Lavin's "A Single Lady". However, Lavin does not simply depict Isabel as such a character in order to reinforce the hysterical spinster stereotype. In a way Isabel herself is also a victim of a society which often discourages women from pursuing a career more ambitious than a domestic occupation. If family duty calls, it is often the daughter rather than the son who has to serve as a homemaker. Isabel's "internal exile" begins when she becomes immersed in her illusion of the

13. Mary Lavin's, The Stories of Mary Lavin, Vol.1 (1964). Hereafter the cited references will be referred to as $M L 1$ with pagination. family's past glory of wealth and status, which has now dwindled, and perceives that her structured household authority (and companionship) are on the verge of collapse. The changed circumstances have alienated her from her home, her father and the world (Arndt 2002: 112-3). Lavin portrays painstakingly a society in which a single woman struggles to find a place. In her earlier story "The Long Ago" (1944), Mary Lavin unveils how indifferent and alienated married people generally perceive spinsters to be, as with the following remark: "That annoyed Dolly. It was all she could do not to say something mean - to let Hallie see, for once and for all, that there was a big difference between a married woman and a spinster, and even a widow was not the same as a woman who had never had a man in the house at all!" $(M L 2,123) .{ }^{14}$ The societal ideology functions here to encourage (or conform) men and women into families, the purpose of which is to reproduce and support the prevailing social system. Thus, single women who do not make this specific kind of contribution to society are likely to be condemned as people without authenticity.

Lavin's stories about single Irish women in the 1930s and 40s may look quite bleak. However, a similar image of a society generally hostile towards single women in general continues to appear throughout Irish women's short stories from later periods. A woman's place in Ireland seems to be located only in the private sphere of home, in other words, her husband's home. There is an anxiety inherent in a woman's loss of her own identity including her name which will be replaced by that of her husband after marriage. One strand of a feminist view of spinsters considers them as those who reject marriage out of fear of surrendering female autonomy. Maria Edgeworth (1768-1849) expressed her concerns about this issue when tormented by pressure to get married. ${ }^{15}$

14. Mary Lavin's The Stories of Mary Lavin, Vol.2 (1974). Hereafter the cited references will be referred to as $M L 2$ with pagination.

15. Maria Edgeworth wrote to Sophy Ruxton, n.d. [1802]: "The idea ... of being shewn, \& stared at \& criticised as the author of Prac Ed [Practical Education (1798)] \&c would be highly disagreeable to me [...] I have no doubt that my happiness would be much increased by a union with a man suited.$/$. 
Although Edgeworth was not against marriage, from her subsequent comment on the topic it suggests she did understand well the potential damage of the autonomy renounced by committing to marriage (Morin 2008: 36).

Emma Cooke (1934- ) published a story, "The Foundress", in the 1980s about such a single woman who, once again, was consumed by the hostility of a society which feared and marginalised them. "The Foundress" reflects the impact of Irish feminism from the earlier periods of the 1960s and the 70s, featuring a heroine, Dot, who appears influenced by the feminist-focused works of two contemporary and iconic literary figures, Doris Lessing and Simone de Beauvoir. Cooke's story and character also has parallels with Tennessee Williams' play A Streetcar Named Desire (1947). Cooke tells a story in which a single woman, Dot, goes to join her married sister Ellie after the death of the mother, and at the end goes mad and is sent to a lunatic asylum. Perhaps Cooke takes the inspiration of the main plot and character from Williams' drama and intends to rework it into a version appropriate to her own feminist agenda in order to attack misogynist assumptions and brutal male behaviour. However, unlike Blanche in $A$ Streetcar Named Desire, Dot in "The Foundress" is portrayed as an intellectual rather than as a neurotic, vain woman. Dot prefers her own activities, such as meditating or engaging in feminist-inspired reading, to marriage and bringing up children. These activities are deemed by her sister and others as "useless", and implicitly present Dot as being a parasite on the family because she never married nor does anything for the family. What Dot can offer is not anything which "would mean tuppence to the farmer in the snipe grass or the member of the Irish Country Women's Association" (GM 194). ${ }^{16}$ Dot has to come to

$\%$ to me in character, temper, \& understanding, and firmly attached to me - but deduct any one of those circumstances and I think I should lose infinitely more than I should gain [...] I am not afraid of being an old maid". Here quoted in Christina Morin, 2008: 36).

16. Louise DeSalvo, Kathleen Walsh D'Arcy and Katherine Hogan's A Green and Mortal Sound (2000). Hereafter the cited references will be referred to as $G M$ with pagination. terms with the perception of her as an oddity, the result of her singleness and celibacy, which is beyond her married sister Ellie's comprehension. If being married is the social norm, then being a spinster may mean transgressing social boundaries. Single women are regarded as being abnormal due to the suspicion that they have rejected by choice the "natural" part of a woman's life, wifehood and motherhood. The abnormality of Dot lies in her existence as a woman without a mate which implies an inability to attract attention from men: "“[tell] your reverend sister to get herself raped,'...'Ha, she never did. That was her trouble', Val [Ellie's husband] said" (GM 200). It is suggested at the end of the story that Dot's "dysfunctionality" is linked to a sexual assault by Val. Dot was, in fact, traumatised by rape instead of being sexually repressed or depressed. Val's brutal behaviour towards Dot indicates a misogynistic attitude towards women in general. The assumption is that spinsters must necessarily be sexually repressed, masochistic and lonely and thus only superficially oblivious to marriage. The myth of female masochism, according to Madeleine Leonard, enhances male dominance over women by acts of sexual violence such as rape. Leonard argues that rape is a socially sanctioned and conditioned pattern of male behaviour which "sustain[s] and justif[ies] female subordination to male" (Leonard 1993: 119). This behaviour pattern could also act as a form of social control on women within daily life or marriage and family. ${ }^{17}$ The rape in "The

17. Many Irish women's stories describe such a fear of male sexual violation and aggression. For example, Mary Lavin in "The Nun's Mother", a story of a young woman's escape into a nunnery to avoid male sexual predators. Angela's decision to remain celibate is linked to her fear of men, which is epitomised in her anxiety about a potential sexual violation by a "flasher" in the story. Another story by Mary Dorcey, "The Lift Home", demonstrates Leonard's point by describing the biased assumption that "fallen women", those like prostitutes, should take full responsibility for the outcome of having been sexually attacked by men simply because these women, through their wanton behaviour, arouse male sexual aggression. Angela Bourke's "Ham" expresses the same notion that the woman herself should be liable for any consequences which might be if caused by her "inappropriate" behaviour. ./. 
Foundress" can be construed as male power attempting to suppress female liberal spirit and independence. Dot is a tragic heroine victimised by a culture which has traditionally devalued and dehumanised women as well as one which is particularly hostile towards single women who may represent an underlying threat to male control and traditional family values.

Two stories featuring the typical spinster-asodd-women stereotype were published by Mary Beckett (1926- ) and Angela Bourke (1952- ) in the 1990s. The social anxiety and hostility against single women surface again in these stories. In "Beauty Treatment" (1996), Bourke shows bitterly how crudely and mercilessly people are capable of treating a single woman. Beckett's “A Literary Woman" (1990) suggests a single woman's oddity may be connected to a trauma in her past. The characters in both stories are presented initially as stereotypically odd spinsters. Their unattractive appearance seems to mark their oddity as spinsters in both stories. In Bourke's "Beauty Treatment", the spinster teacher is disliked by her students as an ugly person with an awful personality associated with her spinsterhood. Once more, this story suggests a woman without a mate is pathetic and abnormal: "I said 'I bet she [Miss Carty] never had any boyfriend'. I nearly said 'I bet he'd get sick too"' (BS 88) ${ }^{18}$ Beckett's "A Literary Woman" implies the spinster was viewed as a scary, evil, witchlike figure: "Satan

./ Eileen's "casual" attitude towards interaction with men may be misinterpreted as delivering a flirting message to them. A similar situation is depicted in Clare Boylan's "Confession", Marilyn McLaughlin's "Witchwoman". There are also many Irish women's stories about the act of or the fear of rape, such as the incest in Leland Bardwell's "The Dove of Peace", Mary Dorcey's "The Orphan", "Emma Cooke's "The Foundress"; rape within marriage in Mary Dorcey's "A Sense of Humour", Fiona Barr's “Excursion”, Mary Morrissy's “Agony Aunt"; rape outside home in Clare Boylan's "Confession", Marilyn McLaughlin's "Witchwoman", Stella Mahon's "Knock Three Times", Mary Dorcey's "The Lift Home"; rape threat in Mary Lavin's "The Nun's Mother" and Moya Roddy's "Biddy's Research".

18. Angela Bourke' By Salt Water (1996). Hereafter the cited references will be referred to as $S W$ with pagination was in [her]" $\left(L W\right.$ 124). ${ }^{19}$ The spinsters in "Beauty Treatment" and "A Literary Woman" are either ugly (Miss Carty's pimples and greasy black hair) or unfit (the literary woman's obesity) and both are far from evoking a gentle maternal image (children dislike them). Again, just like Miss Carty in "Beauty Treatment", single women are deemed abnormal because they are assumed to be sexually repressed and depressed due to their single identity, which is, in turn, the consequence of lack of love. However, Beckett's spinster figure suggests that her social dislocation may rather be connected to a trauma from a time she "spent running from some ominous background" in which "incest is suggested" (Sullivan 1995: 10). The issue of domestic violence and sexual abuse in an Irish dysfunctional family seems to be commonly implied in contemporary Irish women's stories. In this case, her relationship with her father is never directly addressed. Instead, readers are given fragmentary memories about her mother: "[it] must have been fear of him [the father] that sent her [the mother] tearing all over the country" ( $L W 134)$. Single women who are mentally ill or hysterical as portrayed in "The Foundress" and "A Literary Woman" are often deemed sexually repressed according to Freudianism. ${ }^{20}$ Ironically, Irish female writers intend to show that these women go insane not because they are sexually depressed but because they have been victims of male sexual violence. Philosopher and theologian Mary Daly argues that stereotypes of single women

19. Mary Beckett's A Literary Woman (1990). Hereafter the cited references will be referred to as $L W$ with pagination.

20. Freudian psychology tends to conjecture that women who are sexually depressed or repressed are likely to become mentally ill. Shulamith Firestone argues that Freudianism tends to contribute to shaping gender roles in a process of "socialization of men and women to an artificial sex-role system" to serve heterosexuality. As a result, people who do not conform to such sexualisation may be categorised as pathologically "abnormal" or "mentally ill". See Chapter 3 "Freudianism: The Misguided Feminism" in Shulamith Firestone, 1970, The Dialectic of Sex, New York: Bantam Books, 6472. 
in effect act as "a false consciousness" serving to conform and suppress women who are likely to violate the "norm" in society (Daly 1978: $386,409)$. Women's staying single for too long is seen as a kind of prolongation of adolescence and avoidance of the responsibilities of adulthood. The adolescent awkwardness associated with this state of being and behaviour (as with Lavin's socially awkward "Miss Holland") inevitably incur a level of suspicion amongst others who have followed the conventional path (O'Brien 1973: 74). This suspicion results in a weight of social coercion upon women to conform to certain social norms within the existing framework.

\section{Spinsters as Social Mothers}

The first half of the twentieth century saw a low rate of marriage and a high percentage of celibacy in Ireland. The Great Famine had led to fundamental social and economic changes which had significant consequences for the situation of women within the traditional Irish family, especially families in rural areas. Women were sometimes forced into circumstances in which they remained single as a result of such economic factors. One such consequence was to view single women as a source of free labour within the household so it may be seen as convenient to keep them single. Single women were generally seen as an invisible group providing labour for no return at home. Spinsters in Irish women's stories are sometimes treated as dependants, surplus women, with no claim to the family inheritance. Throughout history, Irish women's right to inheritance has been marginalised in tandem with their overall social status. ${ }^{21}$ Irish women's identities and wishes always have to "coincide with th[ose] of the head [the father] of the household" (O'Connor 1998: 89). The transfer of property right appears to imply the transfer or inheritance of economic and political power within the family unit. With a

21 . Roughly until the 17 th century, women under Irish customary law were in general denied a right to inheritance of land. The situation improved for Irish women from the 18th century onwards. For more see Mary O'Dowd, 2002, "Property, Work and Home: Women and the Economy c.1170-1850", The Field Day Anthology of Irish Writing: Women's Writing and Tradition, Vol. V, ed, Angela Bourke, Cork: Cork University Press, 464-73. high rate of unmarried population and low fertility in the country, in the post-famine period Irish society had imposed upon women the important role of reproduction (Horgan 2001 "Women's Lives"). The Virgin Mother was worshipped as the role model for Irish women. As a result single women cannot escape the socially imposed obligation that they are to be surrogate mothering figures if not, for whatever reason, able to fulfil the role of wives or mothers. ${ }^{22}$ This expectation is conceived within the framework of a stereotyping perception which assumes the female biological capacity to mother must automatically be expressed through a personal inclination to nurture other people. Therefore, because a spinster has no husband or children to nurture, she is expected to fulfil a generic mothering role. Such women are sometimes forced to remain single against their wishes due to an assumed overriding duty to look after their families. This reality of spinsters as social mothers contradicts the general perception that single women are selfish, and unwilling to sacrifice for others. It seems that too often the single woman is sacrificed by her family, and ironically, she may even be too "selfless" which then has the ultimate consequence that she becomes an old maid. However, single women are not always appreciated by their family for such devotion. Irish female writers explore varied aspects of single women's lives through depictions of "women's difficulties", exemplifying "the confrontation resulting from stereotyping prejudice against unmarried women" (Pratt 1982: 117).

Already in the 1970s, Maeve Kelly (1930- ) was writing stories about unfairness concerning women's inheritance rights and their difficulties in surviving as single women. Women were expected to serve the needs of the family at their own expense. Kelly's "The False God" (1976) and "Journey Home" (1976) are about such issues. In "The False God", Tom, the only son in the family, is confronted by the resistance of his spinster sisters when he seeks to flee back home and take over the family in order to escape his own failure in the outside world. One of Tom's sisters expresses

22. See L. J. Peach's Women in Culture: A Women's Studies Anthology (1998), Oxford: Blackwell, and Mustard (2004). 
openly her resentment towards him owing to the unfair treatment which has blocked her opportunity for education and any independent career prospect as a result of having to look after young Tom and being told she "must not be selfish" $\left(O H\right.$ 176). ${ }^{23}$ It may be presumed convenient for a family to have an unmarried daughter as homemaker and caretaker as she provides wage-free labour. Nevertheless, there is no guarantee that these single women who have undertaken the duty of looking after elderly parents or managing property for the family will necessarily be able to claim a fair share of the inheritance from the family. Conversely single women in these stories are shown as having no claim to the inheritance which is considered to belong naturally to a son instead of to a daughter. Another story by Kelly, "Journey Home", depicts Maura as another example of a sacrificed spinster. She is described in typically stereotypical spinster terms as unattractive, harsh and lonely. After years of managing the farm for her brother, who was overseas with his own family, she finally snaps and shows her frustration at having been exploited by her brother as unpaid labour for the family farm. For years Maura has not had a life for herself. She never had an opportunity for education nor for exploring the world to gain more experience because she had to work on the farm. Later on she ended up being chained to the duty of taking care of her mother who is physically impaired and has to sit in a wheelchair. As a result Maura has missed the opportunity to pursue her own life and marriage. Maura's limited chances for self-development show in her coarse country accent and language, due to lack of education; her clumsy manners; her withered appearance with grizzled hair and her bulging muscles due to years of hard work on the farm. If her brother Sean plans to come back to reclaim the ownership of the farm, the only place for Maura might be a convent. Maura has no share of the family farm nor has she been paid for her work on the farm. Besides, after years of having worked hard and alone on the farm,

23. The stories cited are from Maeve Kelly's Orange Horses (1990). This 1991 collection was a reissue of A Life of Her Own along with some unpublished stories. Hereafter the cited references will be referred to as $\mathrm{OH}$ with pagination.
Maura does not go anywhere except church and she does not have an active social life. She would not be able to find a job to support herself because she does not know anything outside farming. In this way, she was simply treated as an unpaid slave worker instead of a member of the family. Maura's future in terms of survival as a single woman in such circumstances seems distinctly bleak.

A decade after Maeve Kelly wrote "Journey Home" and "The False God", Clare Boylan (1948-2006) provides a similarly ironic story about a tyrannical father and his stereotypical left-over spinster daughters in "Concerning Virgins" (1989) in which, once again, spinsters are kept as a source of free labour and denied property rights. But Boylan's feminist twist on this story provides an ironic happy ending for such spinsters. This story unveils yet again the male dominance prevailing in a typical Irish family. The man in the story attempts strenuously to father his own male heir in order to avoid his ancestral house being passed on to his spinster daughters. It is not rare for daughters in Irish women's stories to be relegated to secondary status or denied a share of the family property if there is a son in the family. The father's resentment of his two spinster daughters for their "plainness" and their "spinster's preoccupation with little pissing spouts" seem to demonstrate a misogynist view of women (CS 321-2). ${ }^{24} \mathrm{He}$ loathes his daughters being untouched (yet unwanted) goods but he still seeks a virgin for himself to bear his legitimate heir to his estate. At the end of the story, the pure virgins he hopes to find in the community turn out, ironically, to be his own daughters who he has intentionally isolated from others for a long time. Ultimately, the tyrannical father's not so happy death (without an heir) sets free the two spinsters, by rescuing them from disinheritance. Women in the stories by Kelly and Boylan are shown as powerless people who sacrifice their prime years for the benefit of their family for neither reward nor recognition, and greatly to the detriment of their basic long-term survival needs. Kelly's heroines are not as fortunate as the ones in Boylan's story in which a kind of

24. Clare Boylan's The Collected Stories (2000). Hereafter the cited references will be referred to as $C S$ with pagination. 
poetic justice prevails. Overall, these stories by Irish women disclose much in respect of the politics of gender roles in the Irish family.

The relegation of single women to a role as a surrogate mothering figure is another aspect of the spinster stereotype. Various versions of the sacrificial woman are exemplified in Irish women's stories about single women. The unmarried daughter Betty in Claire Keegan's (1968- ) "Sisters" (1999) and Martha in Jan Kennedy's (1955- ) "June 23rd" (1985) are two classic representations of single women as social mothers. In "Sister", Betty has to stay back to keep house and mind her elderly father since her sister Louisa has left home for a job and a new life in England. There is a parallel plot in these stories between an unmarried and a married daughter with the latter normally living away from home and only visiting on an occasional basis. In Keegan's "Sisters", the phrase "chalk and cheese" is used to describe the stark difference in appearance (or maybe in destiny too) between the plain Betty and pretty Louisa (AN 146). ${ }^{25}$ Unmarried Betty is depicted thus: "[s]he never goes anywhere. All she ever does is cook and clean and milk the cow she keeps for the house, attends mass on Sundays" (AN 140). Louisa, by contrast, is lively, pretty, married to a wealthy husband with a nice big house and is mother of three children (and still stays young and charming). Louisa seems to fulfil all the aspects of an ideal woman. In contrast, Betty appears dull and withered while Louisa is fulfilled and experienced. There exists a disparity between their lifestyles as well as the attitudes from their father towards them: "[her] father had always favoured Louisa. She had given him the admiration he needed, whereas Betty only fed and clothed and pacified him" (AN 140). At home the father "belittled" Betty's cooking or associates her only with something depressing such as his impending death. The father seems to be happier to see Louisa than Betty. There is a similar plot in "June 23rd" which portrays the dutiful daughter Martha as "a dull companion" whilst Edwina is "so full of life, full of stories

25. Claire Keegan's Antarctica (1999). Hereafter the cited references will be referred to as $A N$ with pagination. and laughter" (FL 179) ${ }^{26}$ Here, single woman's martyrdom sometimes stems from their selfimposed sense of responsibility to fulfil the needs of other people at the expense of their own welfare. For example, in "June 23rd", Martha is expected to give up her job to care for the invalids at home, which she rationalises to herself as follows: "how could I expect an energetic 20-year-old [Edwina] with such talent to give it all up and come home to look after mother and father?" (FL 179). Moreover, it also seems taken for granted by the family that single women who stay home permanently will undertake the household responsibilities for their family. Martha in "June 23rd" complains: "[b]ut then it's easier to have plenty to say if you're only here for two weeks. Easy to have plenty of stories when you have an office full of people to talk to every day, a husband who adores you and a social life that never seems to slow down" (FL 179). Betty's resentment towards Louisa in "Sisters" bursts out at the moment when she realises Louisa simply calculates to take over the place as her sanctuary from a broken marriage. This is at the expense of Betty's peaceful life after she has dedicated her prime years to the family's household needs, including the sacrifice of her own marriage prospects, all without any reward or appreciation.

Irish women's stories demonstrate a social ideology in which women rather than men are expected to sacrifice themselves for the family. When there are only daughters in the family, such as in Claire Keegan's "Sisters", single women are more likely to be expected to be selfless and sacrifice their own life for others. In Kelly's "The False God", the eldest daughter Brigid was forced to give up her potential career as a doctor to assume responsibility for the family in order to be regarded as a decent, unselfish woman. It has been suggested that one strand of Irish conceptions of ideal womanhood is adulterated by a dominant ideology centring around caring and devotion moulding Irish women into a passive, suffering Virgin Mother (O'Connor 1998: 82). This kind

26. Ruth Hooley's The Female Line (1985), Belfast: Northern Ireland Women's Right Movement. Hereafter the cited references will be referred to as $F L$ with pagination. 
of socially imposed role for single women as social mothers seems to have evolved into a deep-rooted ideology which might originate from a collective societal anxiety that spinsters might actually feel self-contained without marriage and motherhood (O'Brien 1973: 74). The expectation that single women will assume a surrogate mothering role may actually function as a social control intimidating women from becoming too "self-contained" within themselves. Perhaps this is because women's traditional value within a patriarchal society lies, to a significant degree, in their dedication of themselves to others rather than in their own achievements through development of individuality.

\section{Conclusion}

The stories examined in this paper depict the hardship of the lives of Irish single women, against the backdrop of a generally hostile public perception and within a social context which presents them as one of two extremes: either as somewhat abnormal social outcasts and sinners or as devotees. These stories depicting single women as prudish or evil, alienated monsters, or as social mothers, reflect a bigotry against female celibacy and demonstrate the imposition of ideologically charged as well as socially imposed roles upon women in a male-dominated Irish social context. The malice displayed routinely by society towards single women may also be interpreted as a reaction against women who appear intelligent or independent, are not content to play a passive role or otherwise do not conform to the socially appropriate roles of submissive wife or mother. Irrespective of whether single women may feel miserable or happily self-contained in a life not centred around a relationship with a man, single women's motives for remaining unmarried seem to incur other people's suspicion to a degree which "legitimises" their representation as social outcasts and oddities. However, the negative connotations attaching to the use of the term "spinster" in respect of an unmarried woman do not seem to be transferred in the same way to the term "bachelor" when applied to an unmarried man (Lakoff 1975: 32-33). Perhaps spinsters are viewed as a threat to the social structure centred around marriage and the procreation so significant to Irish culture and society. Under such a social ideology, women were not considered individuals with their own authenticity in the same way as men were in society. Therefore, suspicion attached to women who did not become wives and mothers according to the pattern followed by most women in society. Moreover, even divorced and widowed women were treated as different from other "normal" women. Single women are frequently assumed to be miserable, lonely or abnormal because of the stereotypes applied to them even if they themselves felt self-contained.

Single women whose lives and destinies feature centrally in the aforementioned stories are neither appreciated by nor welcomed into mainstream Irish society. Not only may single women be blamed because they fail to make a contribution to society as wives and mothers but also they are restricted and monitored or even punished if they violate a social taboo relating to female sexuality. The prevailing social expectation for a woman, which is that she should find a husband in order to complete the so-called "goal of life", underpins a hostile perception of women who do not behave in accordance with this expectation. That perception seems to hold that nothing is worse for a woman than being without a spouse and being barren. Being barren, regardless of whether this is because she is unmarried or sterile, appears the most serious insult that can be levelled at a woman. A "dried-up old maid" is perhaps viewed as a disgrace or even as a burden to the family so women must try hard to pursue this so-called "happiness of life" (marriage). If marriage is deemed the route to happiness in life, then women who reject it must of necessity be deemed to be abnormal.

Double standards in which single women are condemned according to the criterion noted above are frequently encountered in Irish women's short stories. Single women are blamed as useless, on the one hand, if they are left on the shelf unmarried and stay home with parents. On the other hand, such women are generally shown as forced to remain single, and to sacrifice their personal welfare, including marriage and career, in order to undertake their taken-for-granted tasks of looking after elderly parents or the family. They are blamed by family and community for being selfish if they 
do not fulfil these duties, because, belonging to no one else, they are regarded as available to provide free service. Such exploitation of women plays a role in keeping unmarried daughters at home permanently until it is too late for them to make a marriage. The expectation of selflessness fostered by the Madonna ideal reinforces a perception encouraging women to become martyrs willing to sacrifice themselves in various ways for such an ideal. However, in certain stories, marriage may appear as redemption for women, who then avoid the social criticism and sneering levelled against those who remain single. But, at the same time, women may have to surrender their "selves" and their freedom to conform to this traditional view of male- dominated relationships and marriage. In other words, heterosexual relationships and marriage imply women's subordination to men through the fulfilment of prescribed stereotypical social roles. Hence, being a single woman would be an option for women who wish to determine their own destiny in terms of their sexuality and relationships with men. Thus the negative spinster stereotype can be seen as a narrative device used by Irish female writers to expose to a strategy used by society as a means both to intimidate women who intend to stray from the confines of the marriage enclosure and to condemn women who fail to accomplish this goal in life.

\section{Works Cited}

Arndt, Marie. 2002. "Narratives of Internal Exile in Mary Lavin's Short Stories". International Journal of English Studies. Vol. 2.2. 109-122.

Auerbach, Nina. 1982. Women and the Demon: The Life of a Victorian Myth. London: Harvard University Press.

Beckett, Mary. 1990. A Literary Woman. Dublin: Poolbeg Press.

Bourke, Angela. 1996. By Salt Water. Dublin: New Island Press.

Boylan, Clare. 2000. The Collected Stories. London: Abacus.

Byrne, Anne. 2008. "Single Women in Ireland". Eds. Rudolph M. Bell and Virginia Yans. Women On Their Own: Interdisciplinary Perspectives on Being Single. Piscataway, NJ: Rutgers University Press. 16-39.

Clarkson, L. A. 1981. "Marriage and Fertility in Nineteenth-Century Ireland". Marriage and Society: Studies in the Social History of Marriage. Ed. R. B. Outhwaite. New York: St. Martin's Press, 237-55.

Cooke, Emma. 2000. "The Foundress". A Green and Mortal Sound. Ed. Louise DeSalvo, Kathleen Walsh D'Arcy and Katherine Hogan. Boston: Beacon Press, 191-200.

Daly, Mary. 1978. Gyn/Ecology: The Metaethics of Radical Feminism. Boston: Beacon Press.

Froide, Amy M. 2005. Never Married: Singlewomen in Early Modern England. Oxford: Oxford University Press.

Hamilton, Cicely. 1909. Marriage as a Trade. London: Chapman \& Hall.

Haskell, M. 1988. "Paying Homage to the Spinster". New York Times Magazine, 8 May.

Horgan, Goretti. 2001. "Changing Women's Lives in Ireland". International Socialism Journal. No. 91. http://pubs.socialistreview.index.org.uk/isj91/horgan.htm. [retrieved: 7/04/ 2014]

Jeffreys, Sheila. 1985. The Spinster and Her Enemies: Feminism and Sexuality 1880-1930. London: Pandora Press.

Keegan, Claire. 1999. Antarctica. London: Faber and Faber.

Kelly, Maeve. 1990. Orange Horses. Belfast: The Blackstaff Press.

Kennedy, Jan. 1985. "June 23rd". The Female Line. Ed. Ruth Hooley. Belfast: Northern Ireland Women's Rights Movement, 178-82.

Lakoff, Robin. 1975. Language and Women's Place. New York: Harper \& Row.

Lavin, Mary. 1964. The Stories of Mary Lavin. Vol.1. London: Constable. . 1974. The Stories of Mary Lavin. Vol.2. London: Constable. . 1978. Tales from the Bective Bridge. Dublin: Poolbeg Press. 
Leonard, Madeleine. 1993. "Rape: Myths and Reality”. Ed. Ailbhe Smyth. Women's Studies Reader. Dublin: Attic Press.

Morin, Christina. 2008. "Preferring Spinsterhood? Maria Edgeworth, Castle Rackrent, and Ireland". EighteenthCentury Ireland (Iris an dá Chultúr). Vol. 23. 36-54.

Murphy-Lawless, Jo. 1993. "Fertility, Bodies and Politics: The Irish Case”. Reproductive Health Matters. No. 2 Nov. 53-6.

Mustard, Deborah J. 2004. "Spinster: An Evolving Stereotype Revealed Through Film". Journal of Media Psychology. Vol. 4. http://www.calstatela.edu/faculty/sfischo/ spinster.html. [retrieved: 15/10/2012]

O'Brien, Patricia. 1973. The Woman Alone. New York: Quadrangle/The New York Times Book Company.

O’Connor, Pat. 1998. Emerging Voices: Women in Contemporary Irish Society. Dublin: IPA.

Pratt, Annis, et al. 1982. Archetypal Patterns in Women's Fiction. Brighton: Harvester.

Strassmann, Beverly I. and Alice L. Clark. 1998. "Ecological Constraints on Marriage in Rural Ireland". Evolution and Human Behavior. 19. 33-55.

Sullivan, Megan. 1995. "Mary Beckett: An Interview”. Irish Literary Supplement. Vol. 14. No. 2. 10-12.

Received $24^{\text {th }}$ November $2014 \quad$ Last version $12^{\text {th }}$ January 2015

Ann Wan-lih Chang completed a $\mathrm{PhD}$ in contemporary Irish women's literature from the University of Ulster in 2006. She is currently working as assistant professor at the Department of Applied English Language of the Shih-chien University, Kaohsiung Campus, Taiwan. 